\title{
AGC-1 Irradiation Experiment Test Plan
}

\author{
R.L. Bratton
}

May 2006

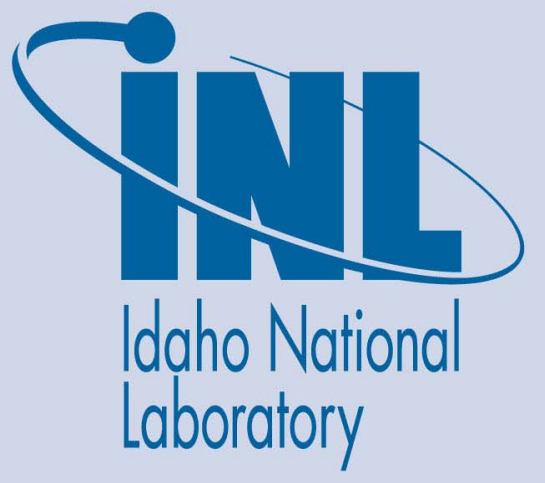

The INL is a U.S. Department of Energy National Laboratory operated by Battelle Energy Alliance 
INL/EXT-06-11102

\title{
AGC-1 Irradiation Experiment Test Plan
}

\author{
R.L. Bratton
}

May 2006

\section{Idaho National Laboratory \\ Idaho Falls, Idaho 83415}

Prepared for the

U.S. Department of Energy

Office of Nuclear Energy

Under DOE Idaho Operations Office

Contract DE-AC07-05ID14517 
This page intentionally left blank. 
AGC-1 Irradiation Experiment Test Plan

INL/EXT-06-11102

Revision 0

May 2006

Signators

Colt 2 Butter

Robert L. Baton

Principle Investigator

NGNP Graphite Qualification Program

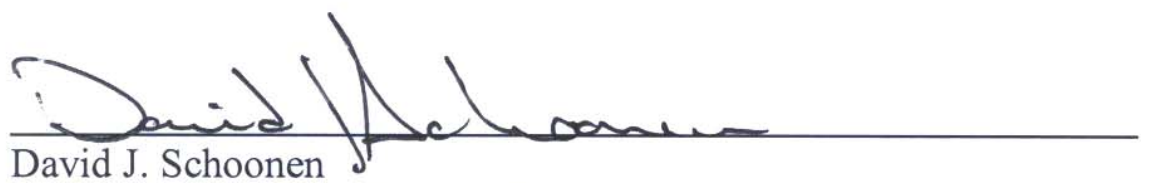

Engineering Projects Support Supervisor

RTC Plant Engineering
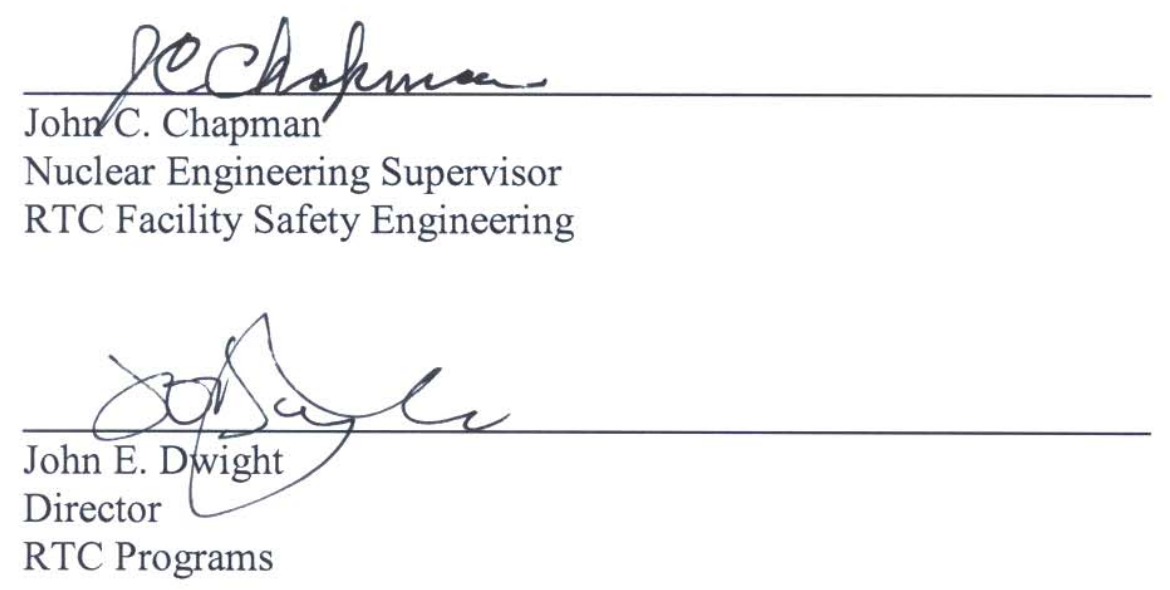
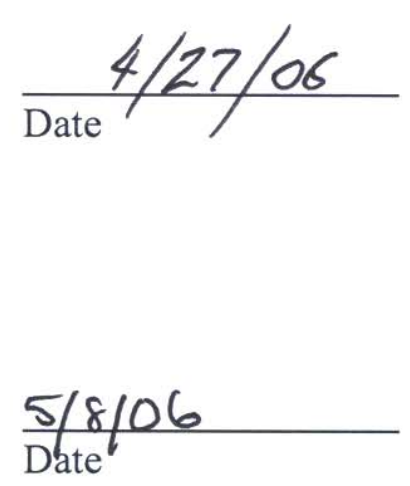

$\frac{1 \text { Why } 2006}{\text { Date }}$

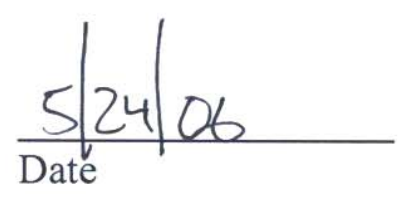

iii 
This page intentionally left blank. 


\section{Executive Summary}

In May 2004, the U.S. Department of Energy (DOE) released a Request for Information and Expressions of Interest on the Next Generation Nuclear Plant (NGNP). This need resulted in the passage of the Energy Act of 2005, which established a program to build and operate a very high temperature reactor (VHTR) to generate electricity and produce hydrogen.

The graphites used previously in the high-temperature gas reactor programs in the United States are no longer in production, and thus replacement graphites must be found. Several new graphites are available for use in the NGNP. These new graphites have no irradiation effects data; hence, it will be necessary to qualify the new grades of graphite for use in the NGNP.

This Advanced Graphite Capsule (AGC) irradiation test program supports the acquisition of irradiated graphite performance data to assist in the selection of the technology to be used for the VHTR. Six irradiations are planned to investigate compressive creep in graphite subjected to a neutron field and obtain irradiated mechanical properties of vibrationally molded, extruded, and iso-molded graphites for comparison. The experiments will be conducted at three temperatures: 600,900 , and $1200^{\circ} \mathrm{C}$. At each temperature, two different capsules will be irradiated to different fluence levels, the first from 0.5 to $4 \mathrm{dpa}$ and the second from 4 to $7 \mathrm{dpa}$. AGC-1 is the first of the six capsules designed for ATR and will focus on the prismatic fluence range.

All six tests will occur at the Idaho National Laboratory (INL)'s Advanced Test Reactor (ATR) over a twelve to thirteen year period. Once a technology has been selected for the NGNP, other irradiation tests, such as a tensile creep test, will be necessary to secure a Nuclear Regulatory Commission (NRC) license. The AGC-1 will be located in the south flux trap in the ATR because of the requirement of space above and below the core and the inherent fast flux levels in the experimental positions.

The major objective of the AGC-1 experiment is to provide irradiation creep rate data. This requires matched pairs of stressed and unstressed samples to be irradiated. This is achieved by using the axial flux symmetry in the ATR to matched specimens within a vertical channel (i.e., the stressed specimens above the core centerline and the unstressed specimens below the core centerline in each channel). This arrangement is used to place six channels around the periphery of a graphite experiment body with a center channel available for non stressed specimens. This grouping maximizes the number of graphite specimen pairs in the experimental position at a temperature of $900^{\circ} \mathrm{C}$ along the 4 -foot length of the core.

Several measurements are needed to demonstrate the AGC-1 has attained the required irradiation conditions, goals, and test specifications. The conditions include graphite specimen time-average peak temperatures, time-average volume-average temperatures, fast fluence, and dislocation per atom values. Only fast neutron fluence measurements will be made for the AGC-1 capsule. The purpose of these measurements is to provide neutron exposure data that will support calculations of the fast neutron fluence and determination of dislocation per atom in the graphite specimens.

All operational activities associated with the AGC-1 experiment will comply with all applicable INL and ATR standard procedures. Further, these activities will comply with all identified safety and quality assurances requirements. 


\section{Contents}

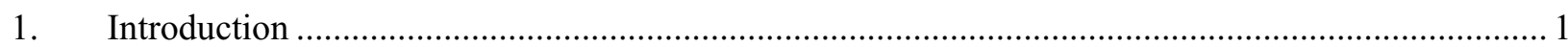

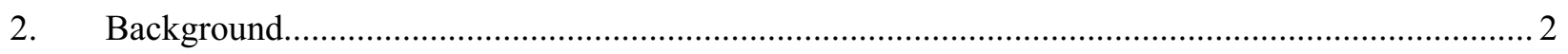

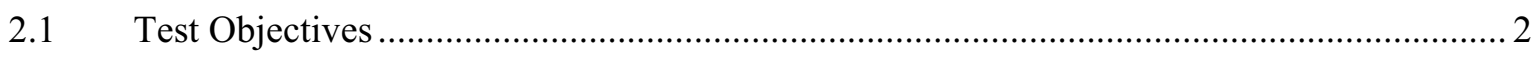

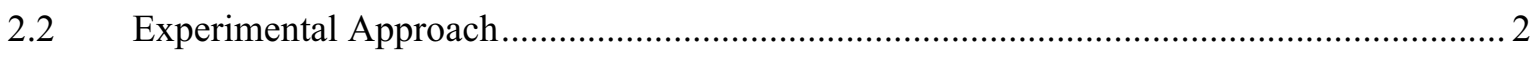

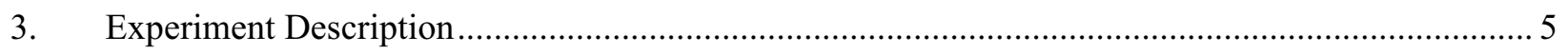

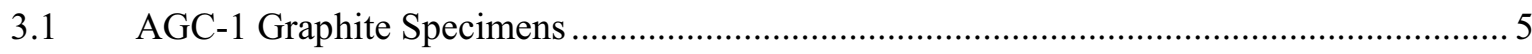

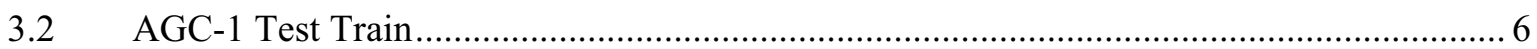

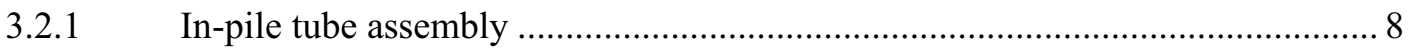

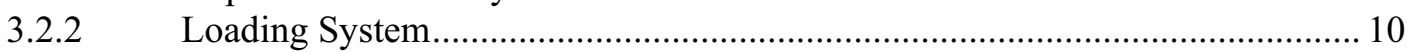

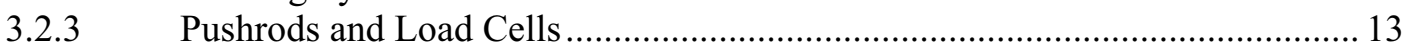

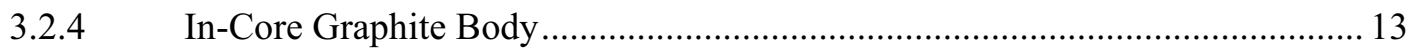

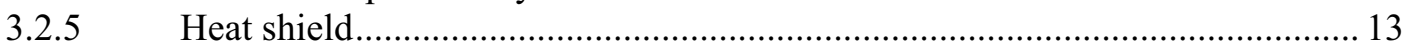

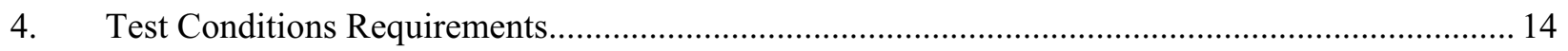

4.1 Internal Heat Generation from Gamma Heating ........................................................ 14

4.2 Temperature Requirements: Nominal operation and PALM cycles................................. 14

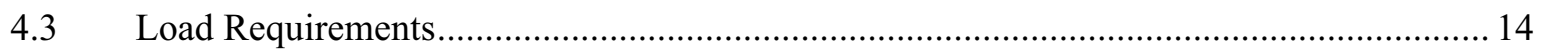

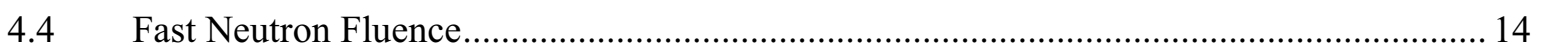

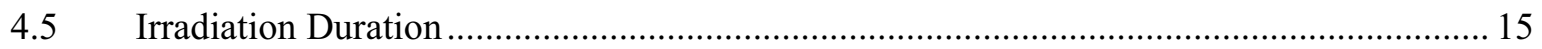

4.6 ATR South Flux Trap Pressure Drop ….................................................................... 15

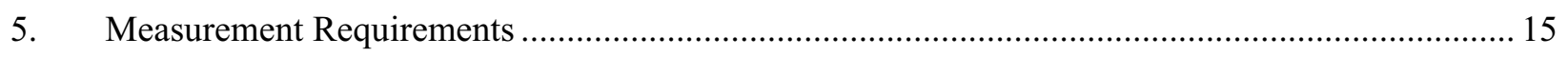

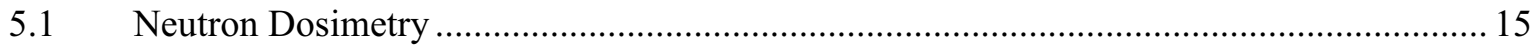

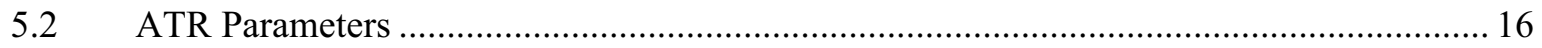

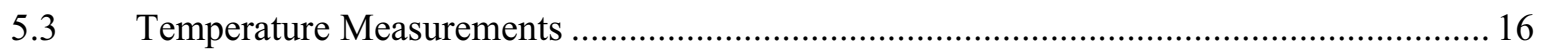

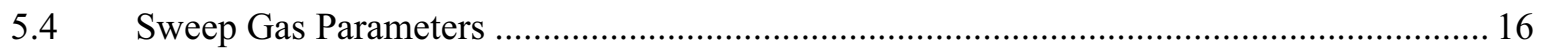

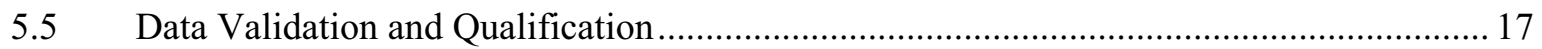

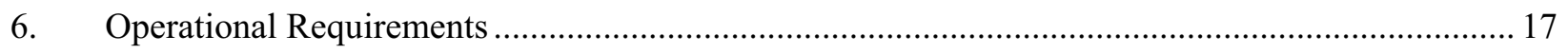

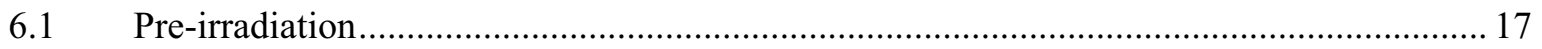

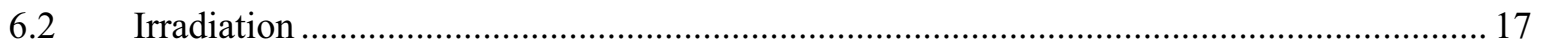

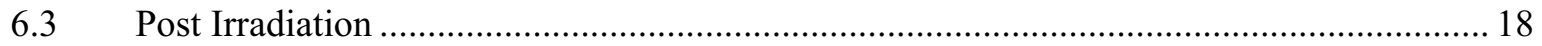

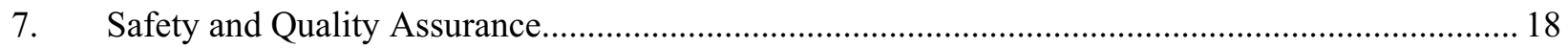

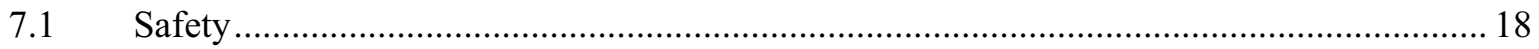

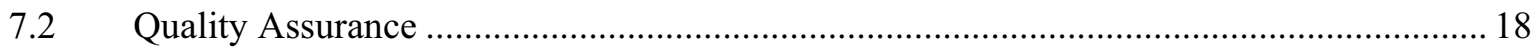

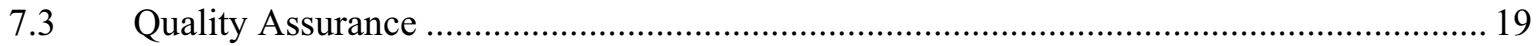

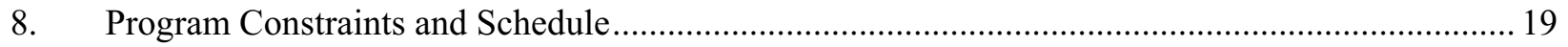

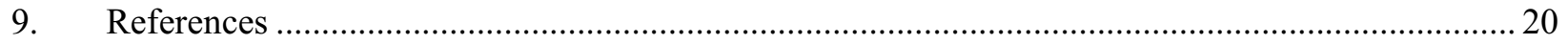




\section{Acronyms}

\begin{tabular}{|c|c|}
\hline $\mathrm{AFCI}$ & Advanced Fuel Cycle Initiative \\
\hline $\mathrm{AGC}$ & Advanced Graphite Capsule \\
\hline ASME & American Society of Mechanical Engineers \\
\hline ASTM & American Society for Testing and Materials \\
\hline ATR & Advanced Test Reactor \\
\hline CGR & gas-cooled reactor \\
\hline DOE & U.S. Department of Energy \\
\hline DOT & U.S. Department of Transportation \\
\hline GA & General Atomics \\
\hline HOPG & highly oriented pyrolytic graphite \\
\hline HTR & High Temperature Reactor \\
\hline HTTR & High Temperature Engineering Test Reactor \\
\hline INL & Idaho National Laboratory \\
\hline JAERI & Japan Atomic Energy Research Institute \\
\hline NGNP & Next Generation Nuclear Plant \\
\hline NRC & Nuclear Regulatory Commission \\
\hline ORNL & Oak Ridge National Laboratory \\
\hline PALM & Power Axial Locator mechanism \\
\hline PBMR & Pebble-Bed Modular Helium Reactor \\
\hline PIE & Post-Irradiation Examination \\
\hline VHTR & very high temperature reactor \\
\hline
\end{tabular}




\section{AGC-1 Irradiation Experiment Test Plan}

\section{Introduction}

In May 2004, the U.S. Department of Energy (DOE) released a Request for Information and Expressions of Interest on the Next Generation Nuclear Plant (NGNP), the objective of which was:

... to conduct research, development, and demonstration of a next-generation nuclear power reactor in order to establish advanced technology for the future production of safe, efficient, and environmentally acceptable power and to demonstrate the economic and technical feasibility of such facilities to the U.S. electric power industry.

This need resulted in the passage of the Energy Act of 2005, which established a program to build and operate a very high temperature reactor (VHTR) to generate electricity and produce hydrogen. This reactor will be a graphite-moderated, helium-cooled thermal reactor capable of producing electricity and hydrogen as a demonstration plant for the NGNP.

The NGNP reference concept is a helium-cooled, graphite-moderated, thermal neutron spectrum reactor with an outlet temperature of 900 to $950^{\circ} \mathrm{C}$ or higher and a 40 - to 60 -year operating life. The reactor core is currently envisioned to be a prismatic graphite block-type core. However, it is feasible to also consider a pebble-bed gas-cooled reactor (GCR).

The graphites used previously in the high-temperature gas reactor programs in the United States are no longer in production, and thus replacement graphites must be found. Further, renewed interest in VHTR concepts, such as the prismatic Gas Turbine Modular Helium Reactor and the Pebble-Bed Modular helium Reactor (PBMR), has prompted graphite manufacturers to develop new nuclear grade graphites through discussion with the reactor vendors and graphite experts. Consequently, several new graphites are available for use in the NGNP. These new graphites have no irradiation effects data; hence, it will be necessary to qualify the new grades of graphite for use in the NGNP. Potential candidates currently exist, including: fine-grained isotropic, molded or isostatically pressed, high-strength graphite suitable for core support structures, fuel elements and replaceable reactor components, as well as nearisotropic, extruded, nuclear graphite suitable for the above-mentioned structures and for the large permanent reflector components. These candidates most likely will exceed the American Society for Testing and Materials (ASTM) D 7219 - 05, "Standard Specification for Isotropic and Near-isotropic Nuclear Graphites," materials specification for nuclear grade graphite. 


\section{Background}

Graphite-irradiated mechanical and thermal properties are required to design a nuclear reactor core using graphite as the structural material. Unlike nuclear fuel, which is replaced on a periodic basis, the graphite structure remains in-place. The length of time the graphite remains in the core depends on the fluence accumulation, the service temperature, and the grade of graphite used, but the prospective graphite candidates have no irradiation history. This Advanced Graphite Capsule (AGC) irradiation test program supports the acquisition of irradiated graphite performance data to assist in the selection of the technology to be used for the VHTR.

\subsection{Test Objectives}

The mechanism of neutron irradiation damage in graphite is well understood; however, the relationships of specific structures at the micro and macrostructural level to the irradiation behavior are less understood. Thus, an extensive irradiation program is needed to develop the data needed for models relating structure to the irradiation behavior for the new graphites of interest.

Six irradiations are planned to investigate compressive creep in graphite subjected to a neutron field and obtain irradiated mechanical properties of vibrationally molded, extruded, and iso-molded graphites for comparison. Other historical and lesser grades of graphite will be irradiated to provide linkage with past graphite irradiations. The experiments will be conducted at three temperatures: 600, 900 , and $1200^{\circ} \mathrm{C}$. At each temperature, two different capsules will be irradiated to different fluence levels, the first from 0.5 to $4 \mathrm{dpa}$ and the second from 4 to $7 \mathrm{dpa}$. Each capsule will start with unirradiated graphite samples. These capsules will be denoted by AGC-1 through AGC-6. AGC-1 is the first of the six capsules designed for ATR and will focus on the lower prismatic fluence range. All six tests will occur at the Idaho National Laboratory (INL)'s Advanced Test Reactor (ATR) over a twelve to thirteen year period. Once a technology has been selected for the NGNP, other irradiation tests, such as a tensile creep test, will be necessary to secure a Nuclear Regulatory Commission (NRC) license.

\subsection{Experimental Approach}

The AGC-1 will be located in the south flux trap in the ATR, as shown in Figure 1. This position was chosen because of the requirement of space above and below the core and the inherent fast flux levels in the experimental positions. The east flux trap has an established program operating in its location. The center flux trap is smaller than the south flux trap thereby severely restricting the quantity of graphite samples. The other ATR positions that are not occupied are too small or have insufficient fast flux and space above and below the core to accommodate the experiment. Additionally, the south flux trap is usually operated at higher power levels than the Northeast flux trap or the North and Northwest loops. 


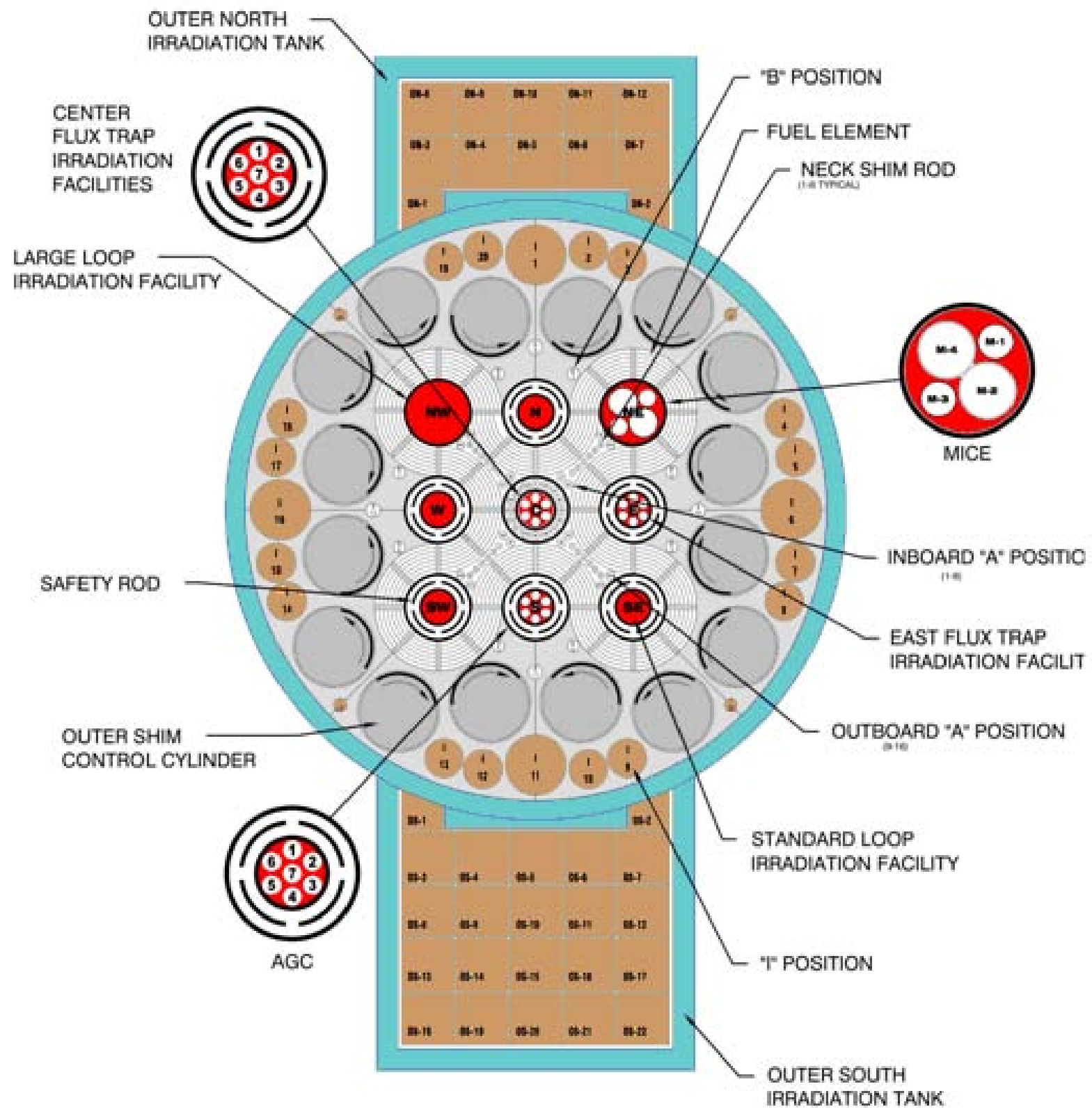

Figure 1. Experimental positions in the Advanced Test Reactor core.

The AGC-1 capsule provides design data on the effects of irradiation on NGNP relevant graphites over the neutron dose range $0.53 \times 10^{21} \mathrm{n} / \mathrm{cm}^{2}-5.8 \times 10^{21} \mathrm{n} / \mathrm{cm}^{2}[\mathrm{E}>0.1 \mathrm{MeV}]$ or 0.39-4.2 dpa at an irradiation temperature of $900^{\circ} \mathrm{C}$.

The data to be obtained from this irradiation capsule include:

- Irradiation creep design data and data on the effects of irradiation creep on key physical properties (strength, elastic modulus, coefficient of thermal expansion) 
- The effects of neutron irradiation on the properties of a wide range of NGNP-relevant graphites, including dimensional changes, strength, elastic modulus, thermal conductivity, and coefficient of thermal expansion. Data on the single-crystal irradiation behavior of graphites will be derived from highly oriented pyrolytic graphite (HOPG).

The graphite grades to be included in the AGC-1 capsule can be categorized as follows.

A. Major Grades. These graphites are reactor vendor's candidates for the core structures of NGNP, and include four new grades (NBG-17, NBG-18, PCEA, and IG-430) as well as two historical (reference) grades (H-451 and IG-110). These grades are most likely to receive reasonably large neutron doses in their lifetime and will be subjected to significant stresses in operation. Therefore, these grades occupy the stressed and companion unstressed position in the capsule and yield irradiation creep data.

B. Minor Grades. PGX- and HLM-grade graphites are most likely to be used in low neutron dose regions such as the permanent reflector and the core support pedestals.

C. Alternate Grades. Alternate grades are those that NGNP members and vendors have identified as being of interest to compare irradiated performance of petroleum versus coal coke graphites or extrusion versus iso-molded graphites. Grades NBG-10, NBG-25, PCIB, and PPEA are in these categories.

D. Experimental Grades. Two experimental graphites are included in AGC-1 (BAN and A3 matrix). BAN graphite is an experimental grade whose manufacturing process and raw materials are such that it should offer superior irradiation stability. A3 matrix is the blend of graphites and carbonized phenolic resin used as the matrix in the NGNP fuel compact or fuel pebble. Samples of A3 are to be obtained from the Advanced Fuel Cycle Initiative (AFCI) program and will be produced at Oak Ridge National Laboratory (ORNL).

E. Single Crystal Graphite. The dimensional change behavior of graphite is particularly significant to the behavior of polycrystalline (polygranular) graphites. Therefore, samples of HOPG are included in AGC-1.

The AGC-1 irradiation capsule contains six pneumatic pistons to apply controlled loads to the graphite creep samples located in six peripheral channels of the capsule (see lower left quadrant of Figure 1). The employed loads are based on: (a) historic norms and (b) detailed discussions with reactor vendors via the America Society of Mechanical Engineers (ASME) graphite core design project team. In addition, each of the six peripheral channels in AGC-1 contains companion unstressed graphite specimens. The apparent irradiation creep strain may be determined from the difference in the dimensional changes between a stressed and unstressed sample irradiated at the same temperature and to the same neutron damage dose. In addition to the unstressed creep control samples, each peripheral channel contains a number of smaller, so-called "piggyback" samples of VHTR relevant graphites. These piggyback specimens do not provide irradiation creep data, but do provide valuable irradiated physical properties data.

The center channel of AGC-1 accommodates a large number of piggyback samples as well as silicon carbide $(\mathrm{SiC})$ temperature monitors. The $\mathrm{SiC}$ temperature monitors provide a post irradiation check on the irradiation temperature and allow for affirmation of the real time temperature data from the capsule thermocouples. 
These creep data will also support the generation of ASME graphite core design rules. In the past, deterministic approaches were used for graphite core design. However, pending NRC rule making will require that a probabilistic design approach be used for these high-temperature graphite core designs. The prior irradiated graphite creep experiments are for graphites which are no longer available and do not support the ASME rule making. The AGC-1 will contain enough graphite irradiated creep data to fulfill the ASME needs as well as pending NRC requirements.

\section{Experiment Description}

Section 3.1 discusses the background and the expected information that will be obtained from the graphite AGC-1 specimens, while Section 3.2 describes the functionality of the ACG- 1 test train. The test train is composed of in-pile tube assembly, the loading system, push rods/load cells, in-core graphite body, and the heat shield.

\subsection{AGC-1 Graphite Specimens}

The graphite specimens have been selected from various new and old graphite grades. The selection strategy used to select these graphites is found in NGNP Graphite Testing and Qualification Specimen Selection Strategy, INL/EXT-05-00269, May 2005 ${ }^{[1]}$. Table 1, Graphite Selection Matrix, is reproduced from the selection strategy document and identifies the graphites that will be irradiated in AGC-1.

Table 1. Graphite Selection Matrix

\begin{tabular}{|l|l|l|l|l|}
\hline Graphite & $\begin{array}{l}\text { Reactor } \\
\text { Designer }\end{array}$ & \multicolumn{1}{|c|}{ Proposed Use } & \multicolumn{1}{|c|}{$\begin{array}{c}\text { Capsule } \\
\text { Location }\end{array}$} & \multicolumn{1}{|c|}{ Remarks } \\
\hline H-451 & GA & $\begin{array}{l}\text { Prismatic fuel element } \\
\text { and replaceable reflector. }\end{array}$ & Creep & $\begin{array}{l}\text { Historical Reference. } \\
\text { Only a few samples. } \\
\text { Grain size } \sim 500 \mu \mathrm{m}\end{array}$ \\
\hline IG-110 & $\begin{array}{l}\text { JAERI } \\
\text { China }\end{array}$ & $\begin{array}{l}\text { Prismatic fuel element, } \\
\text { replaceable reflector, and } \\
\text { core support pedestals. }\end{array}$ & Creep & $\begin{array}{l}\text { Historical Reference. } \\
\text { Only a few samples. } \\
\text { Currently being used in the HTTR and } \\
\text { HTR-10. } \\
\text { Grain size } \sim 10 \mu \mathrm{m}\end{array}$ \\
\hline PCEA & AREVA & $\begin{array}{l}\text { Prismatic fuel and } \\
\text { replaceable block. } \\
\text { Pebble bed reflector and } \\
\text { insulation blocks. }\end{array}$ & Creep & $\begin{array}{l}\text { AREVA wants to construct the entire } \\
\text { graphite core out of the same graphite. } \\
\text { Grain size } ~ 76 \mu \mathrm{m}\end{array}$ \\
\hline NBG-18 & PBMR & $\begin{array}{l}\text { Prismatic fuel element } \\
\text { and replaceable reflector. } \\
\text { Pebble bed reflector } \\
\text { structure and insulation } \\
\text { blocks. }\end{array}$ & Creep & $\begin{array}{l}\text { Candidate for PBMR replaceable } \\
\text { reflector. } \\
\text { Grain size } \sim 160 \mu \mathrm{m}\end{array}$ \\
\hline NBG-17 & AREVA & $\begin{array}{l}\text { Prismatic fuel element } \\
\text { and replaceable reflector. } \\
\text { Pebble bed; reflector } \\
\text { structure and insulation } \\
\text { blocks. }\end{array}$ & Creep & $\begin{array}{l}\text { AREVA wants to construct the entire } \\
\text { graphite core out of the same graphite. } \\
\text { NBG-17 is finer grain than NBG-18. } \\
\text { Grain size } \sim 80 \mu \mathrm{m}\end{array}$ \\
\hline
\end{tabular}




\begin{tabular}{|c|c|c|c|c|}
\hline Graphite & $\begin{array}{l}\text { Reactor } \\
\text { Designer }\end{array}$ & Proposed Use & $\begin{array}{l}\text { Capsule } \\
\text { Location }\end{array}$ & Remarks \\
\hline IG-430 & JAERI & $\begin{array}{l}\text { Prismatic fuel element, } \\
\text { replaceable reflector, and } \\
\text { core support pedestals. }\end{array}$ & Creep & $\begin{array}{l}\text { JAERI wants to use this graphite in the } \\
\text { GTHTR } 300 \text {. } \\
\text { Grain size } \sim 10 \mu \mathrm{m}\end{array}$ \\
\hline HLM & & $\begin{array}{l}\text { Prismatic large } \\
\text { permanent reflector. }\end{array}$ & Piggyback & $\begin{array}{l}\text { Fort St. Vrain permanent reflector. } \\
\text { Similar to PGX. } \\
\text { Grain size } \sim 76 \mu \mathrm{m}\end{array}$ \\
\hline PGX & $\begin{array}{l}\text { AREVA } \\
\text { JAERI }\end{array}$ & $\begin{array}{l}\text { Prismatic large } \\
\text { permanent reflector. }\end{array}$ & Piggyback & $\begin{array}{l}\text { AREVA may use this material; } \\
\text { preference is to use PCEA or NBG-17 for } \\
\text { permanent reflector. HTTR permanent } \\
\text { structure. } \\
\text { Grain size } \sim 76 \mu \mathrm{m}\end{array}$ \\
\hline NBG-25 & & Core support candidate. & Piggyback & $\begin{array}{l}\text { Isostatic fine grain. } \\
\text { Grain size } \sim 10 \mu \mathrm{m}\end{array}$ \\
\hline 2020 & & $\begin{array}{l}\text { Prismatic core support } \\
\text { pedestals and blocks. }\end{array}$ & Piggyback & $\begin{array}{l}\text { Fine grain isotropic. } \\
\text { NPR candidate material. } \\
\text { Grain size } \sim 15 \mu \mathrm{m}\end{array}$ \\
\hline PCIB & & Core support candidate. & Piggyback & $\begin{array}{l}\text { Fine grain isotropic. } \\
\text { Grain size } \sim 75 \mu \mathrm{m}\end{array}$ \\
\hline BAN & & & Piggyback & $\begin{array}{l}\text { Experimental graphite with potentially } \\
\text { superior irradiation life. } \\
\text { Grain size } \sim 80 \mu \mathrm{m} \text { This graphite is not } \\
\text { commercially available }\end{array}$ \\
\hline NBG-10 & PBMR & $\begin{array}{l}\text { Prismatic Fuel element } \\
\text { and replaceable reflector. } \\
\text { Pebble bed; reflector } \\
\text { structure and insulation } \\
\text { blocks. }\end{array}$ & Piggyback & $\begin{array}{l}\text { PBMR's original choice for replaceable } \\
\text { reflector. } \\
\text { Price/performance will be the basis } \\
\text { between NBG-18 and NBG-10. } \\
\text { Grain size } \sim 160 \mu \mathrm{m}\end{array}$ \\
\hline HOPG & & $\begin{array}{l}\text { Needed to determine } \\
\text { change in crystalline } \\
\text { structure. }\end{array}$ & Piggyback & $\begin{array}{l}\text { Provides insight to single crystal changes } \\
\text { during neutron irradiation. }\end{array}$ \\
\hline A3 Matrix & & $\begin{array}{l}\text { Needed to determine fuel } \\
\text { compact irradiated } \\
\text { material behavior. }\end{array}$ & Piggyback & \\
\hline PPEA & & $\begin{array}{l}\text { Prismatic fuel and } \\
\text { replaceable block; } \\
\text { Pebble bed reflector and } \\
\text { insulation blocks }\end{array}$ & Piggyback & $\begin{array}{l}\text { Comparison of irradiation performance } \\
\text { between petroleum and pitch coke } \\
\text { Grain size } \sim 76 \mu \mathrm{m}\end{array}$ \\
\hline
\end{tabular}

\subsection{AGC-1 Test Train}

The major objective of the AGC-1 experiment is to provide irradiation creep rate data. This requires matched pairs of stressed and unstressed samples to be irradiated. This is achieved by using the axial flux symmetry in the ATR to matched specimens within a vertical channel (i.e., the stressed 
specimens above the core centerline and the unstressed specimens below the core centerline in each channel). This arrangement is used to place six channels around the periphery of a graphite experiment body with a center channel available for non stressed specimens (see Figure 2). This grouping maximizes the number of graphite specimen pairs in the experimental position. The graphite grades are distributed throughout the peripheral channels in the AGC-1 capsule such that the failure of any one of the channels will not jeopardize the entire data set for any single graphite grade. Additional graphite grades are located in the graphite bodies' center channel where no load will be applied. These graphites will be irradiated to determine the effects on physical properties

The stressed samples in the peripheral channels will be loaded by pneumatic pistons or rams using a combination of stainless steel and graphite pushrods. The rams will be located above the core away from the high neutron and gamma fields of the ATR core. The rams' force is transmitted by the stainless steel pushrods. Graphite pushrods are attached to the stainless steel pushrods to transmit the force inside the high-temperature graphite body. The force on the graphite channel is monitored by an in-line load cell between the stainless steel and graphite pushrods. The load cell juncture is located at an elevation above the core. The pressure within each pneumatic piston will be continuously monitored to maintain the design stress level. These rams will be designated as the primary rams.

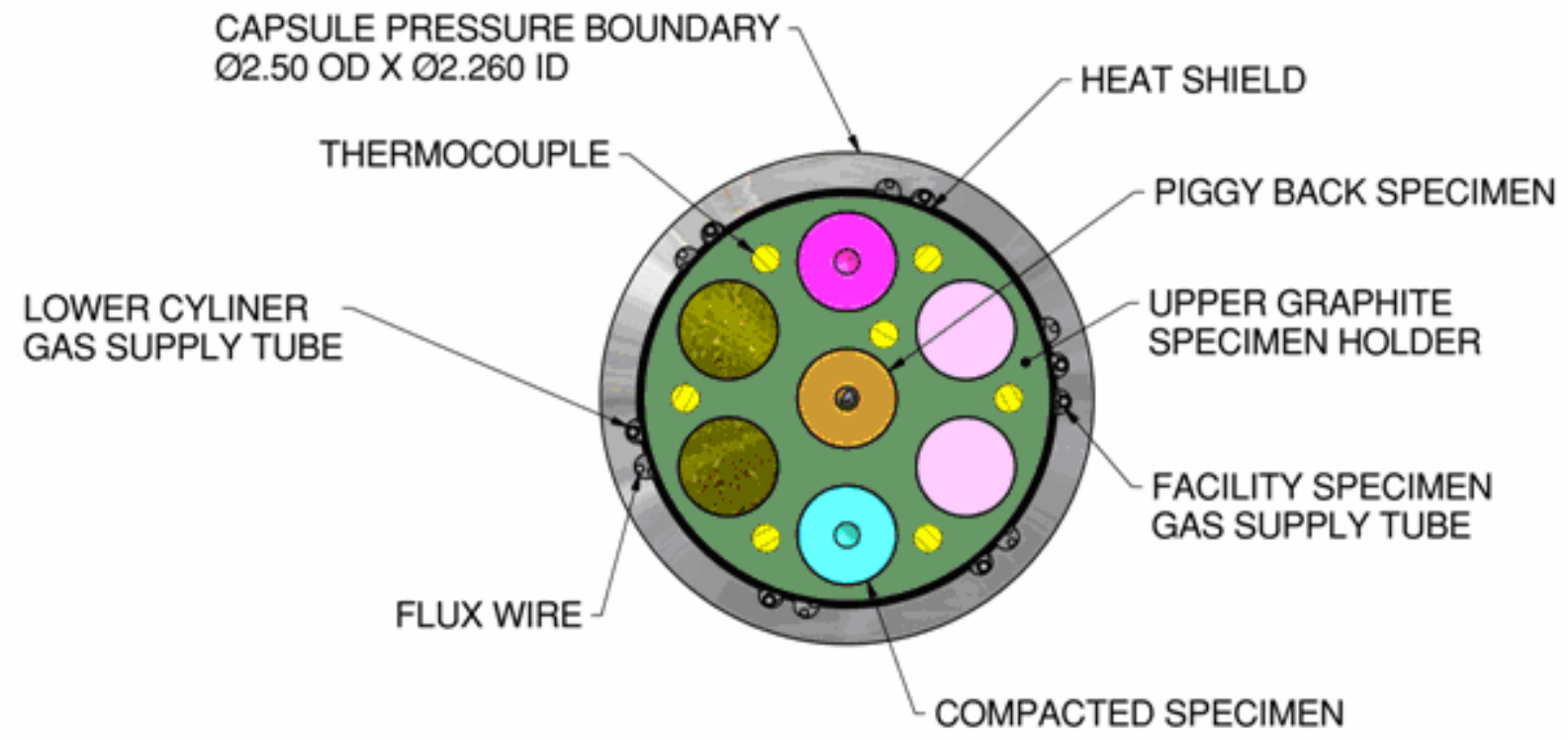

Figure 2 Cross-section of the AGC-1 capsule

Each peripheral channel will have a second pneumatic ram located at the bottom of the capsule below the core, which is capable of displacing the graphite sample stack. These rams will be designated as the secondary rams. During reactor outages, when the primary ram load is removed, the graphite specimen stack is "upset" by displacement from the lower rams. This procedure will assure that the graphite stack is not jammed in the channel and, thus, that the applied load is actually being transmitted to all of the stressed specimens in the channel. The high temperature in the core necessitates a graphite pushrod be used to transmit the rams' force to the specimen stack. This provision is based on prior creep capsule operating history and experience.

During operation, the capsule will maintain a constant compressive load and specimen temperature during reactor power level changes. An axial temperature is achieved by the design of the gas gaps and ratio of He and Ar sweep gases used to set up quasi-stagnant gas conduction gaps between components. The gaps are the radial spaces between concentric components filled with the sweep gas mixture. To a 
lesser extent, radiation heat transfer also controls the temperature. The primary heat source for the graphite capsule is the interaction of the core's gamma field with the materials in the capsule. The gamma heat intensity follows the axial chopped cosine flux shape resulting in a decrease in heat generation in the upper and lower ends of the capsule. Obtaining an axial temperature in the capsule is accomplished by linearly increasing distances between capsule components. At core centerline, the gaps are at their narrowest and then increase to their maximum separation at the top and bottom of the capsule. This is achieved by designing the graphite body with a variable outside diameter with a thermal radiation heat shield having a constant outer diameter with a variable wall thickness.

Twelve thermocouples are distributed along the 48-inch axial length of the graphite body. Each successive thermocouple will be four inches deeper than the prior thermocouple. Any one of the 12 thermocouples' signals can be used as input for the temperature control system. SiC temperature monitors will be installed in the interior of the experiment and will be interrogated during Post Irradiation Examination (PIE) for the maximum temperature in the experiment.

The fast neutron fluence (for $\mathrm{E}>0.1 \mathrm{MeV}$ ) will be measured by six flux wires $(2 \mathrm{Fe}, 2 \mathrm{Ni}$, and $2 \mathrm{Nb}$ ). The flux wires will be located in the outer pressure boundary, a relatively cold region of the capsule. The extreme heat in the graphite body could thermodynamically promote formation of carbides on the flux wire metals resulting in flux wires forming material bonds in contact with the graphite body. These potential material bonds make removal of the flux wires difficult. For this reason, the flux wires and gas lines have been located in the outer pressure boundary. The expected irradiation duration is approximately 170 full power reactor days to achieve the required fluence range.

\subsubsection{In-pile tube assembly}

The experiment is contained in a modified loop-experiment in-pile assembly (see Figure 3). This configuration was chosen to establish a dry isolated chamber inside the reactor vessel and core. The experiment tube becomes a pressure vessel inside the ATR reactor vessel. The tube has an internal pressure of one atmosphere with the ATR operational pressure of 26.2 atmospheres applied to the external boundary. ATR technical specifications limit the outer temperature of the tube to prevent departure of nucleate boiling in the reactor coolant. The tube wall temperature is controlled by introducing a variable composition of He and Ar. The amount of temperature drop across the small gaps is controlled by the mixture of $\mathrm{He}$ and Ar gas introduced into the capsule.

The in-pile tube hangs from the vessel head approximately 26 feet into the vessel cavity and core and is fabricated from 304L and 316L stainless steel pipe. The first 13 feet has an outer diameter of five inches. The second 13 feet has a short transition from five inches to 2.5 inches. A section of tube with a 2.5 -inch outer diameter runs the remainder of the length. The vessel formed by the in-pile tube is designed and analyzed to ASME Section III, Class 3 pressure vessel specifications. 

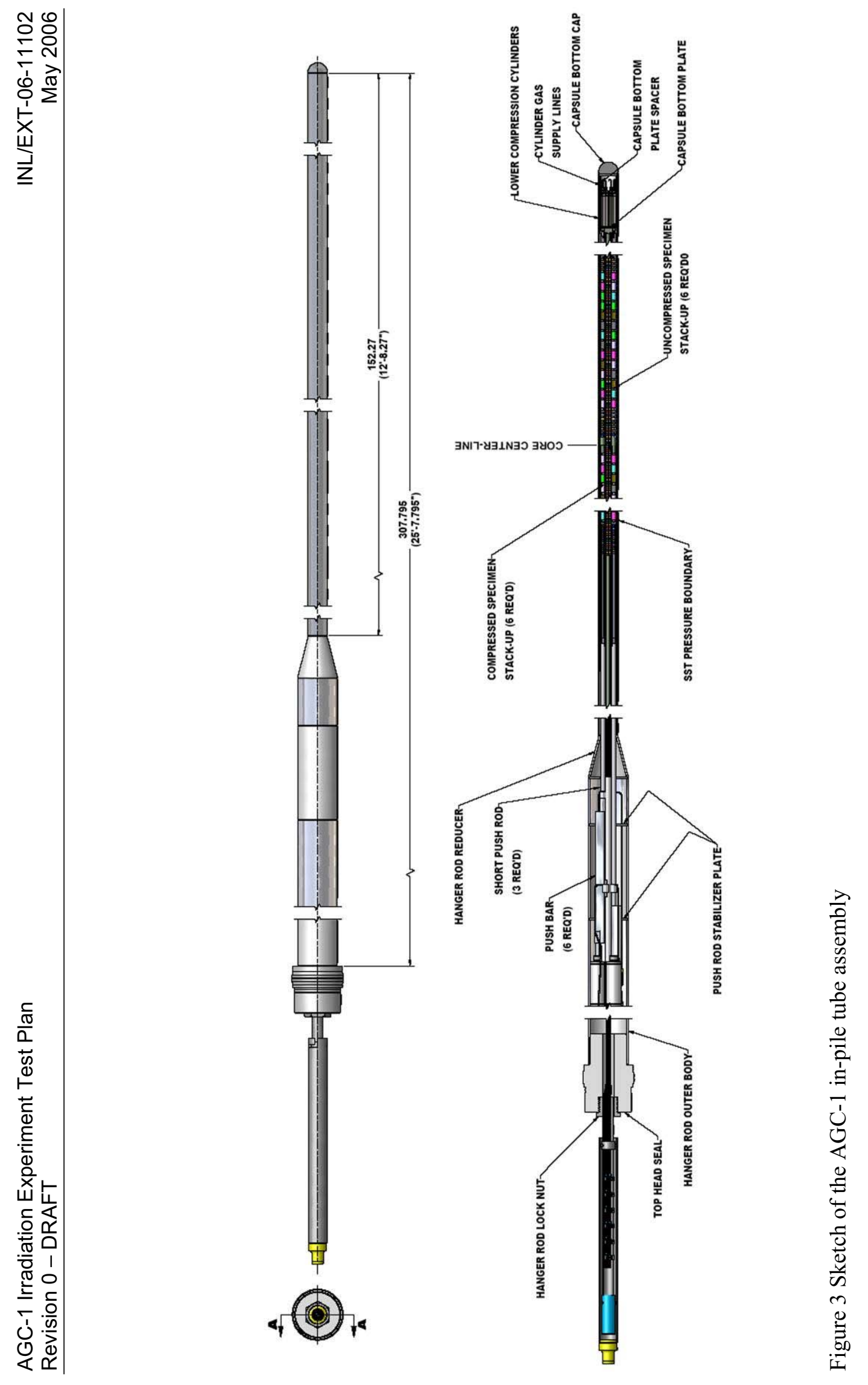


\subsubsection{Loading System}

Prior graphite compressive creep capsule irradiations performed at ORNL and INL used pneumatically loaded graphite specimens in columns distributed in a graphite body. The most extensive series of graphite compressive creep irradiations were the OC series performed at ORNL ${ }^{[2]}$. An important lesson learned from these experiments will be incorporated into the AGC series of capsules. In the OC series, besides the pneumatic bellows above the stack used for loading the graphite specimens, additional pneumatic bellows were placed below the specimen stack to upset the stack during reactor outages and ensure specimens in the stack did not become jammed against the graphite body holder and render the stack unresponsive to the applied load. This type of arrangement of bellows above and below the core could only be achieved in the ATR flux traps because no other positions in the ATR core available to the program has sufficient space above and below the core (see Figure 4).
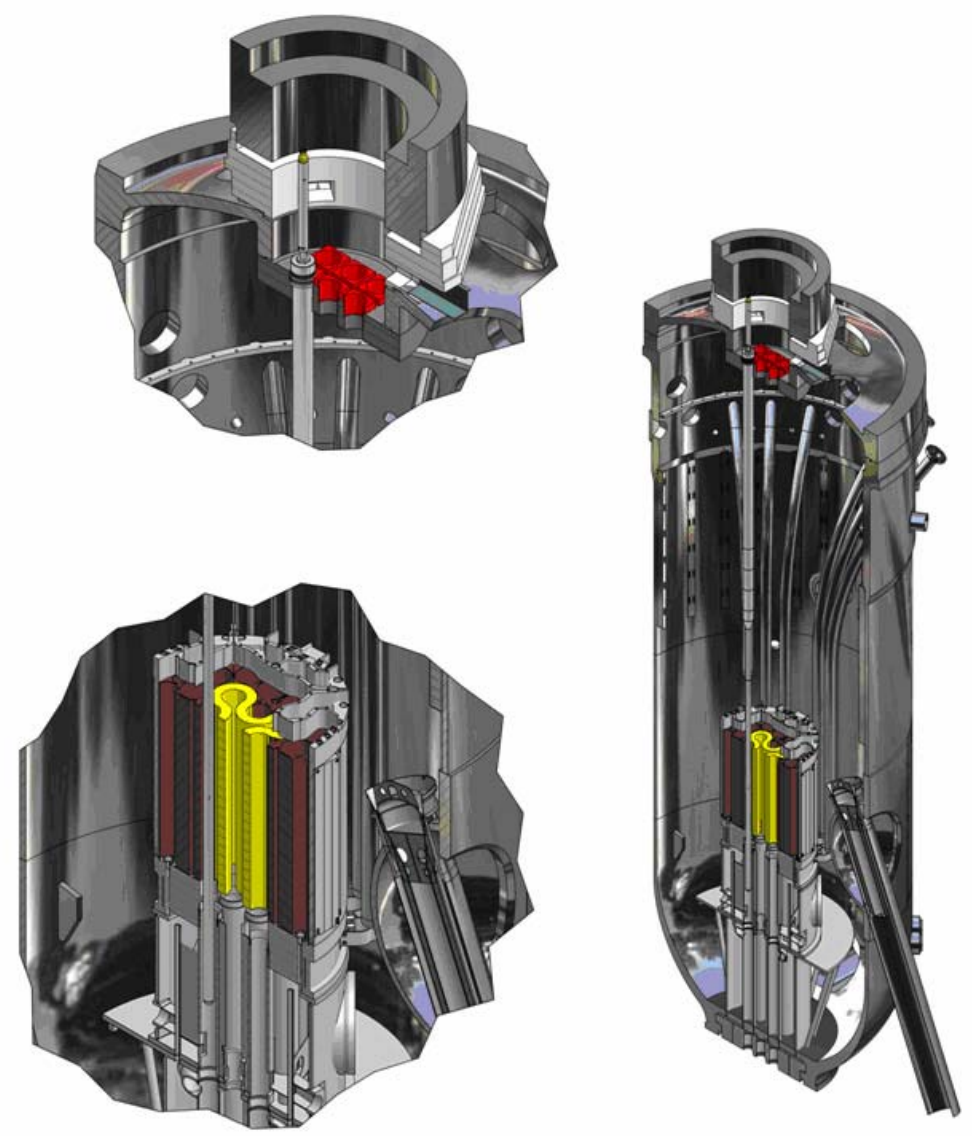

Figure 4. Cutaway of the ATR core showing the space above and below the experiment will occupy.

After further consideration, the use of pneumatic bellows in the AGC capsule series to load the graphite channels was considered a greater risk than using off-the-shelf common pneumatic cylinders or rams. Fabrication of a bellow requires metal plates be welded on both ends of corrugated bellows stock with one of the plates tapped for a pressure fitting. The welded bellows then has to be calibrated for displacement and force versus applied pressure. The bellows used in the OC capsules were 1-inch in diameter and operated at high pressures, 48.2 atmospheres ( 854 psia), to obtain the force necessary to achieve the desired compressive loads. The use of those bellows in the ATR core could pose safety issues because the bellows are not ASME-certified pressure vessels. As described in Section 3.2, commercially available pneumatic rams will be used in the AGC capsules that operate at pressures less than 16.8 
atmospheres ( $250 \mathrm{psia}$ ) and provide the same mechanical force as the 1-inch bellows. The commercial pneumatic rams are larger than the bellows, thus the design should be optimized to use the space in the upper in-pile tube. The ram's arrangement should also align with the six graphite channels. The ram's size and pressure will be analyzed to deliver the $2 \mathrm{ksi}$ and $3 \mathrm{ksi}$ loads required in the graphite columns. Figure 5 shows a possible layout of the pneumatic rams in the upper assembly.

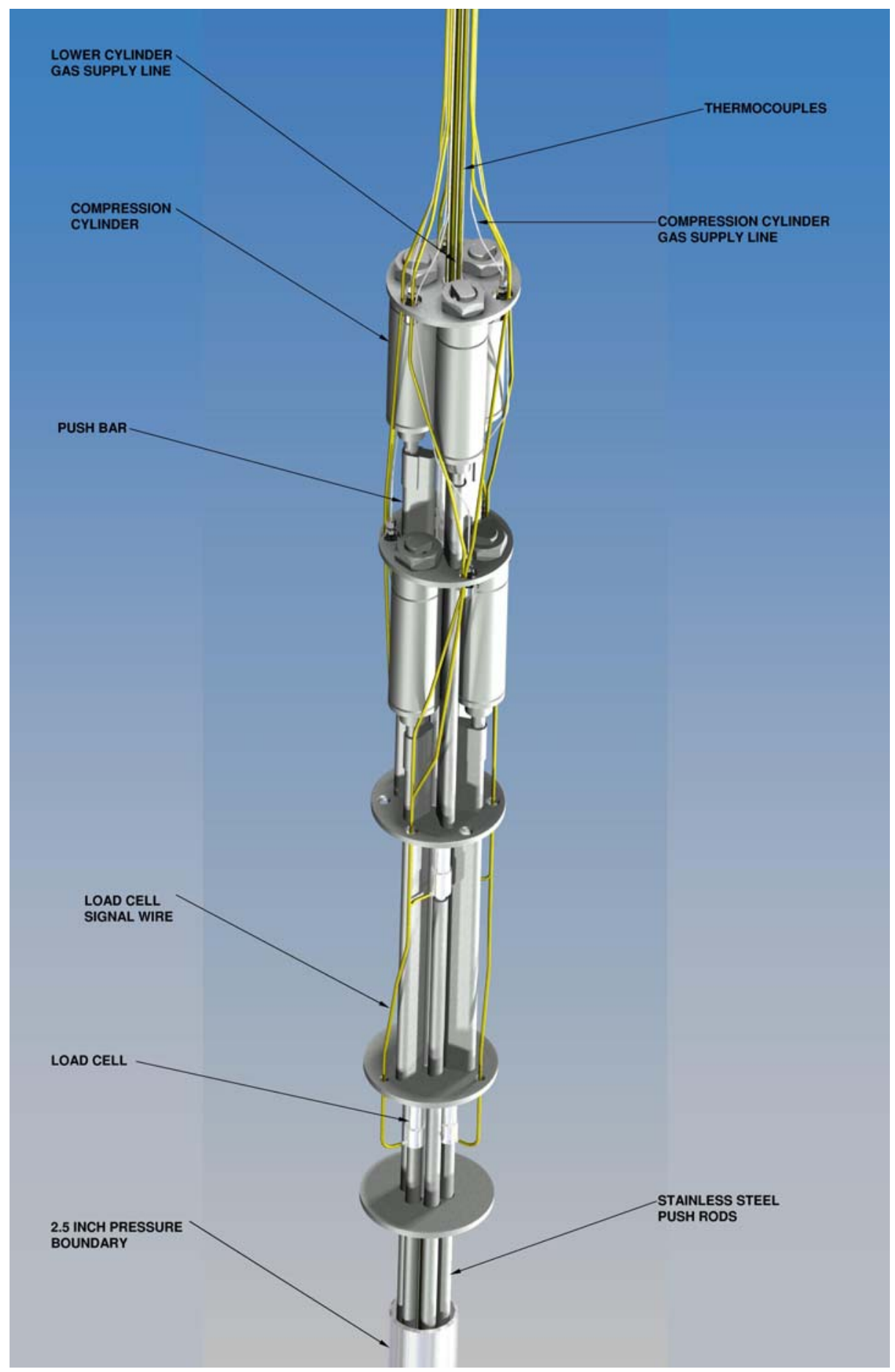

Figure 5. Cutaway of the upper AGC-1 capsule showing the arrangement of the pneumatic rams and load cells used to load the 6 graphite channels. 
The size of the pneumatic rams used in the bottom of the experiment is expected to be much smaller because they only need to lift the stack of graphite without the applied load of the upper rams. As with the upper rams, the design should arrange the lower rams directly inline with the six graphite channels locations. These cylinders will be located below the core away from the high neutron and gamma fields (see Figure 6).

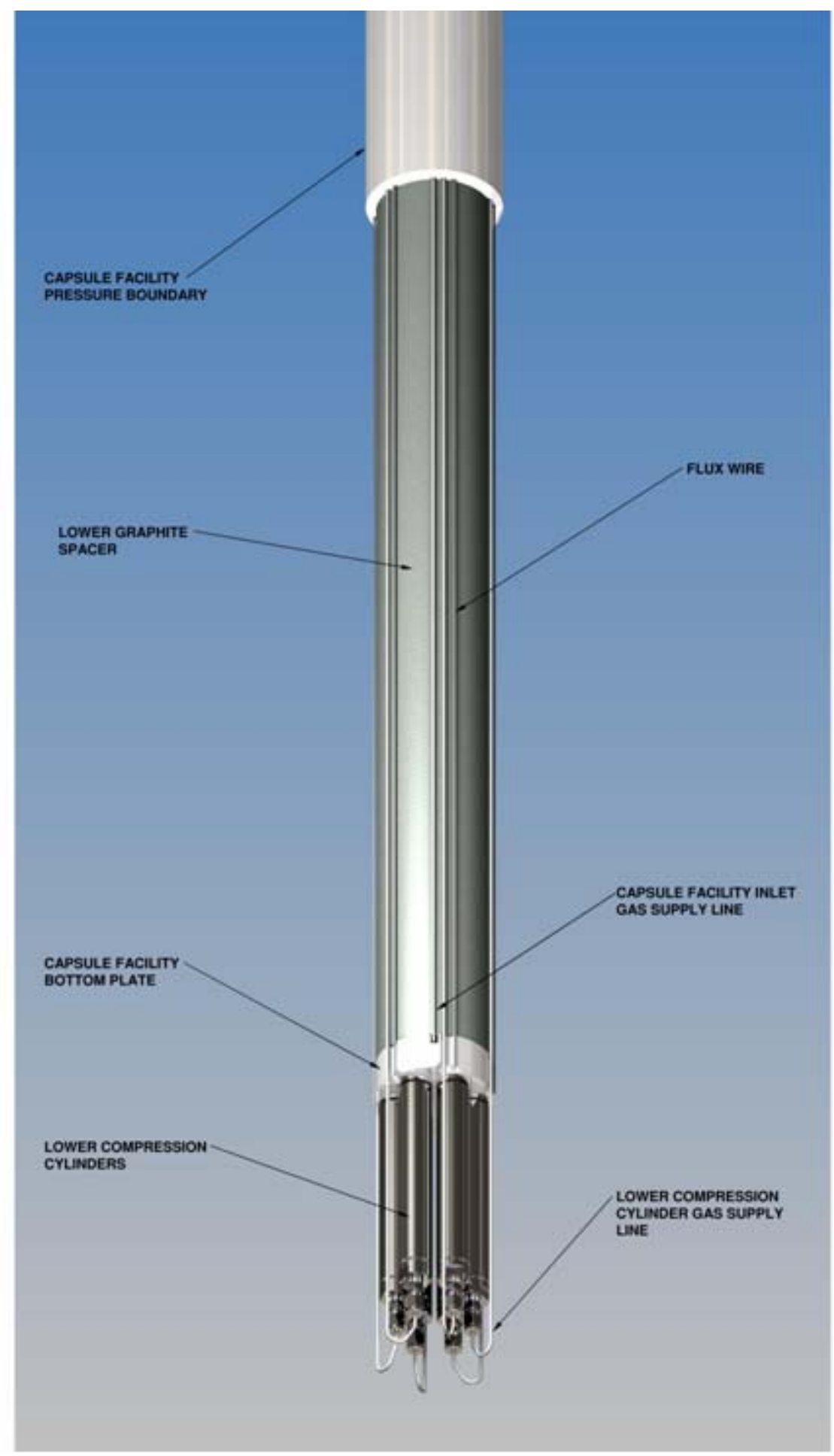

Figure 6. Location of the six pneumatic rams on the bottom of the capsule. 


\subsubsection{Pushrods and Load Cells}

Pushrods are used to impart the rams' force on the graphite channels. Stainless steel push rods and appropriate supports should be design to resist buckling under load. In the core region of the capsule, the stainless steel push rods will be weakened by the extreme temperatures. Graphite push rods should be employed in the core to avoid this issue. In-line load cells will be used to measure the applied loads on the graphite columns. The load cells should be located away from the core to avoid high neutron and gamma fields near the core. The load range of the load cell should have minimum of -500 and a maximum 500 lbs. The load cell should not have more than a $\pm 1 \%$ error in the reported load.

\subsubsection{In-Core Graphite Body}

The graphite body should be sized to hold six 0.5 -inch diameter graphite specimen columns with a 0.5 -inch diameter graphite column in the center. Twelve blind thermocouple holes should be co-located among the seven 0.5 -inch through holes. The depth of each successive thermocouple hole should be four inches deeper. The length of the graphite body should extend beyond the core region to ensure there is no abrupt temperature transition at the ends of the capsule. The graphite chosen for the graphite body and push rods should be high-strength, fine-grain, and isotropic graphite with an extensive irradiation history. The thermal conductivity should be consistent within the billet to ensure uniform heat transfer in multiple pieces machined from the billet. The ash content should be less than $300 \mathrm{ppm}$, as required by the ASTM D7219-05, "Standard Specification for Isotropic and Near-Isotropic Nuclear Graphites." Irradiated mechanical properties must be available from open published data.

At the core centerline, a mechanical method should be employed to load the upper stack of graphite specimens and prevent loading the lower stack of graphite specimens. The method should allow the displacement of the entire stack upward. A mechanical method should also be employed to align the specimens within the through specimen holes. The graphite body should be designed using no less than three axial bodies doweled together. One joint should be at the core centerline with the second joint above and below the core. The outer contour of graphite body should be designed and analyzed to promote the greatest heat transfer at core centerline with the least amount of heat transferred at the capsule ends to maintain a nearly constant $900^{\circ} \mathrm{C}$ axial temperature profile. Fluence-dependent thermal and mechanical properties should be used in the thermal and mechanical analysis of the graphite body.

\subsubsection{Heat shield}

A thermal heat shield is necessary to reduce the radiation heat transfer from the graphite body to the metallic outer pressure boundary. Radiation heat transfer directly to the pressure boundary would enhance the temperature control of the test. A metallic heat shield shall be designed and analyzed to impede the thermal radiation heat transfer and act as a secondary heat source for the experiment. The gamma heat decreases quickly at the ends of the capsule; this can be compensated by increasing the thickness of the heat shield. The metal would need to resist carburization/decarburization at temperatures of $800^{\circ} \mathrm{C}$. Because of the low cobalt content, the heat shield should be fabricated from Haynes 230 alloy. 


\section{Test Conditions Requirements}

Section 4 presents the irradiation conditions expected for the AGC-1 experiment. The design will be capable of maintaining temperatures and loads during normal and Power Axial Locator Mechanism (PALM) cycles.

\subsection{Internal Heat Generation from Gamma Heating}

The heat generated in the capsule is entirely from gamma heat; no heaters are employed. In the core, intense gamma fields interact with the capsule materials generating heat in the material. The amount of heat is proportional to the density of the material. Typical peak gamma heat for graphite and metals in the ATR is approximately $10 \mathrm{~W} / \mathrm{g}$, obtained from preliminary neutronic scoping calculations ${ }^{[3]}$. The flux shape over the 4 -foot height of the core is a chopped cosine shape curve. The flux decays quickly at the top and bottom of the core; therefore, the amount of heat generated the will vary with the flux profile.

\subsection{Temperature Requirements: Nominal operation and PALM cycles}

The experiment will maximize the number of specimens at a temperature of $900^{\circ} \mathrm{C}$ along the 4 -foot length of the core. Since the flux decreases rapidly at the ends of the capsule, maintaining a uniform axial temperature profile in the test would require additional design complexity of questionable safety. Thus, the graphite samples at the ends of the test will see lower temperatures than $900^{\circ} \mathrm{C}$.

ATR usually operates with the Southeast and Southwest lobes at different power levels. This condition creates a flux gradient in the East to West direction in the flux trap. This is especially true during PALM runs. There is an additional flux gradient in the North to South direction in the south flux trap. Both of these flux gradients result in asymmetric heating in the capsule. If other fissile experiments are operated in the ATR core in the vicinity of the south flux trap during this irradiation, the accumulative effect could reduce or exacerbate the North to South flux gradient. The number of specimens achieving $900^{\circ} \mathrm{C}$ temperature will be acceptable by allowing a volume and time average temperature margin over the specimen of $\pm 20^{\circ} \mathrm{C}$. Instantaneous peak temperature for each specimen shall be $<950^{\circ} \mathrm{C}$. The capsule analysis will assess the variability in the axial and radial heat generation to estimate the specimen temperature distribution.

\subsection{Load Requirements}

Two loads will be applied to the graphite columns. Three columns will be loaded with a $2 \mathrm{ksi}$ load and the other three columns will be loaded with a $3 \mathrm{ksi}$ load. The load will be generated by six pneumatic rams located in the upper section of the in-pile tube (see Sections 3.2 and 3.2.2). Pushrods will transmit the force of the ram's piston onto the graphite columns creating the loads in the upper stack of the graphite specimens (see Section 3.2.3). The loading system will have the capabilities to compensate for thermal expansion and expected graphite shrinkage during the experiment. This will be accomplished by using feedback from in-line load cells between the pneumatic rams and pushrods to maintain the correct pressure in the cylinders.

\subsection{Fast Neutron Fluence}

The volume average fast neutron fluence for the graphite specimens will be inferred from physics calculations normalized by the flux wire measurements performed after capsule disassembly. This 
requires the half-life of the radioisotope to be of sufficient time to limit reduction in activity by radioactive decay, taking into account the time required to remove the capsule from ATR, transport the capsule to ORNL, and disassemble the capsule. This is necessary to ensure the activity is sufficient for acceptable counting times and statistics. The flux wires have been chosen to measure the fast spectrum greater than $0.18 \mathrm{MeV}$. Characteristics of the proposed flux wires are listed in Table 2.

Table 2 Flux Wire Information

\begin{tabular}{|c|c|c|c|}
\hline Material & Reaction & $\begin{array}{c}\text { Reaction-Product } \\
\text { Half Life }\end{array}$ & $\begin{array}{c}\text { Neutron Activation } \\
\text { Energy Range }\end{array}$ \\
\hline $\mathrm{Fe}$ & $\mathrm{Fe}-54(\mathrm{n}, \mathrm{p}) \mathrm{Mn}-54$ & 312 days & $1 \mathrm{MeV}$ Threshold \\
\hline $\mathrm{Nb}$ & $\mathrm{Nb}-93\left(\mathrm{n}, \mathrm{n}^{\prime}\right) \mathrm{Nb}-93 \mathrm{~m}$ & 16 years & $0.18 \mathrm{MeV}$ Threshold \\
\hline $\mathrm{Ni}$ & $\mathrm{Ni}-58(\mathrm{n}, \mathrm{np}) \mathrm{Co}-57$ & 272 days & $10 \mathrm{Mev}$ Threshold \\
\hline
\end{tabular}

\subsection{Irradiation Duration}

Based on preliminary physic scoping calculations the capsule will need to reside in the ATR south flux trap for 170 effective full power days. This will result in graphite specimens receiving a fast fluence of 0.5 to 4 dpa.

\subsection{ATR South Flux Trap Pressure Drop}

The pressure drop in the cut-off dummy in-pile tube shall be in compliance with the Technical Safety Requirements for ATR, TSR-186, Section 3/4 Operational Limits and Surveillance Requirements, rev. 9, subsection 3.3.1.4 Core Differential Pressure.

\section{Measurement Requirements}

Several measurements are needed to demonstrate the AGC-1 has attained the required irradiation conditions, goals, and test specifications. The conditions include graphite specimen time-average peak temperatures, time-average volume-average temperatures, fast fluence, and displacement per atom values. The fast neutron fluence and temperatures will be inferred from physics and thermal calculations that require supporting measurement data. Each of these measurement categories are discussed below.

\subsection{Neutron Dosimetry}

Only fast neutron fluence measurements will be made for the AGC-1 capsule. Thermal neutron fluence does not cause significant material damage to warrant measurement. The purpose of these measurements is to provide neutron exposure data that will support calculations of the fast neutron fluence and determination of dislocation per atom in the graphite specimens. This support may consist of a set of point values used to normalize physics calculations.

Following irradiation and test train disassembly at ORNL hot cell facilities, the six flux wires, described in Section 4.4, will be removed from each capsule. The flux wires will then be prepared and counted for their neutron-induced radionuclide activities. Counting uncertainties will stay within specified limits of $\pm 10 \%$. Data collected from the neutron monitors will be corrected for decay according to standard procedures. Derived fast neutron fluence data will be further corrected to energies greater than $0.1 \mathrm{MeV}$. At all times, identification information (monitor type, serial number or similar code, 
original test train location, etc.) will remain with each neutron monitor. These data should be transmitted in a reviewed report to the INL to be incorporated into the final physics calculations of the capsule.

\subsection{ATR Parameters}

Advanced Test Reactor data that describes the core neutronics and thermal-hydraulics environment will be required. These data will be used to assist physics analysis necessary for the final test report. Data that will be provided include individual lobe powers, shim cylinder positions, and vessel inlet temperatures. These data will be recorded and backed up on a separate storage device once every minute. ATR lobe powers will be provided by ATR engineering within five working days of the end of each reactor cycle of irradiation.

\subsection{Temperature Measurements}

Temperature measurements will be performed by twelve thermocouples spaced every four inches in axial core height in the graphite body. The thermocouples are also spaced azimuthally around the graphite body. These measurements will be used to support thermal analyses of the graphite body and specimens. One thermocouple is designated as the controlling thermocouple providing feedback to the computerized temperature control system that adjusts the sweep gas blend to maintain a reference temperature. If the controlling thermocouple should fail, one of the other remaining thermocouples is selected to control the temperature.

AGC-1 thermocouple types are being evaluated for the conditions of the experiment. However, these thermocouples will have at least an installed accuracy of $\pm 2 \%$ of reading. During normal and abnormal operation, thermocouple data will be recorded and backed up on a separate device once every minute.

\subsection{Sweep Gas Parameters}

The capsule will use a mixture of $\mathrm{He}$ and Ar to control the temperature in the capsule. During normal ATR operations, the gas mixture should be nearly constant, but ratio changes will be expected as power is modified with burnup. Moreover, the capsule will be left in during PALM cycles requiring large changes to the $\mathrm{He} / \mathrm{Ar}$ gas ratio to meet the $900^{\circ} \mathrm{C}$ temperature profile. To effect these changes, several measurements must be made and recorded regarding the pressure and mass flow rates of each constituent.

The He and Ar shall be of research grade, $99.999 \%$ pure. The moisture and oxygen content is a concern. As such, both gases will pass through a desiccant and an oxygen getter before entering the capsule. Moreover, the moisture and free oxygen will be measured before the gas mixture enters the capsule. In addition, the $\mathrm{CO}$ and $\mathrm{CO}_{2}$ content of the exit gas will be measured to determine to what extent, if any, oxidation has taken place. All gas and mass flow measurement will be electronically recorded on five minutes intervals with remote backup. The data necessary of capsule integrity that will be recorded are:

- He and Ar purity (from gas sample analysis upon receipt)

- Mass flow He and Ar going into mixing valve

- Total gas flow into experiment

- $\mathrm{O}_{2}$ /Moisture levels of gas into experiment

- $\mathrm{CO} / \mathrm{CO}_{2}$ of gas exiting the experiment. 


\subsection{Data Validation and Qualification}

All electronically recorded data will be evaluated for validation and qualified for use. It is currently planned that a commercial software package will process the data for this purpose. The following parameters will be evaluated: thermocouple temperatures, pneumatic ram pressures, constituent sweep gas flow rates and pressure, load cell output, and measured sweep gas inlet and outlet species.

\section{Operational Requirements}

All operational activities associated with the AGC-1 experiment will comply with all applicable INL and ATR standard procedures. Further, these activities will comply with all safety and quality assurances requirements outlined in Section 7. Activities requiring special or unique consideration are identified below.

\subsection{Pre-irradiation}

Prior to final test assembly, confirmatory physics, thermal, and mechanical analysis will be completed and reviewed using material properties appropriate for the ATR operating conditions, including PALM cycles. Temperature and fluence dependent properties should be used to predict graphite specimen temperatures and stress levels. Both thermal and physics analysis will be performed on the capsule prior to the cycle start up. This analysis will take into account the specified power in the South lobe and possible changes in ATR core configurations for the cycle.

Following the receipt, inspection, and verification of the AGC-1 experiment materials, the entire test train will be assembled, inspected, and tested. The load train will be tested to ensure load cell response, and the "upset" rams at the bottom of the capsule will be tested to ensure the specimens move freely. Continuity checks will be performed on thermocouples prior to reactor insertion. Following these activities, a review will be conducted whereby findings will be corrected.

Following successful completion of the review and obtaining all appropriate ATR approvals, the AGC-1 test train will be inserted into ATR's South flux trap. Air in all pneumatic ram gas and temperature control gas lines will be purged and backfilled with Helium to a pressure to be determined later. The pressure will be monitored to ensure no leaks exist in the experiment.

\subsection{Irradiation}

During irradiation, temperature and pneumatic ram pressure control is automatically maintained by the gas control system. This system requires temperature feedback from a control thermocouple chosen out of the twelve in the capsule. Should a control thermocouple fail, a previously selected back-up thermocouple will be used as the control thermocouple, and the reference control temperature will be reset based on pre-cycle thermal analysis predictions. Should all thermocouples fail, results from the physics and thermal analysis supported by the operating history of the Southeast and Southwest lobes will be used to manually set the gas blends of the affected capsule. Ultimately, should all thermocouples fail within the test, temperature control may be based on predictive thermal analyses.

Similarly, the pressure in the pneumatic rams loading the graphite specimens is controlled from feedback from the six load cells. Should a load cell fail, a previously selected load cell will be used to control the pressure in the ram, taking into account the previously recorded pressures in the cylinder. Should all load cells fail, results from the physics and thermal analysis supported by the operating history of the Southeast and Southwest lobes will be used to manually set the gas pressure in the six pneumatic 
rams. Ultimately, should all load cells fail within the test, load control may be based upon predictive thermal analyses.

Should the reactor trip for an unanticipated fault, the pressure in the six pneumatic rams should be dumped and the sweep gas mixture switched to all Helium. Program participants may be able to view real-time data on-line via a secured web site. Viewable data should include all electronic data collected by the data recording computer.

As a result of cycle-to-cycle variations in ATR lobe powers, accumulated burnup and fast neutron fluence for the AGC-1 capsule must be periodically updated based on as-run data. These as-run data reports will be issued after each cycle.

\subsection{Post Irradiation}

The AGC-1 test train will be removed from the reactor after completion of the irradiation. For removal, the thermocouple leads, load cell leads, and gas lines will be disconnected at the hanger rod manifold. The AGC-1 test train will then be moved to the ATR canal by transfer cask.

After completion, the test train will remain in the canal until the activity is at a level that allows for the resizing of the experiment in the canal. The experiment will be sized to fit the GE 2000 cask for transportation to ORNL for further disassembly and PIE. Development of the sizing apparatus will begin in FY 06 and is expected to be completed by FY 07.

A Quick-look Irradiation Test Results report will be issued six weeks after shipment of the GE 2000 cask to ORNL. The Final Irradiation Test Report will be issued four weeks after the flux wires have been counted and the capsule disassembled and inspected at ORNL.

\section{Safety and Quality Assurance \\ 7.1 Safety}

The in-pile assembly is designed and fabricated as an ASME Section III, Class 3 pressure vessel. This activity makes the risk of reactor coolant leaking into the assembly extremely remote. Nevertheless, if reactor coolant leaks into the assembly and results in overpressure of the in-pile assembly, ex-core pressure monitoring equipment will relieve the internal capsule pressure and send a signal to the experiment operator for immediate manual reactor scram. Upon ATR reaching a safe shutdown mode, the AGC-1 experiment will be removed from the core and an equivalent dummy experiment inserted.

If one of the pneumatic rams were to leak without intervention, the experiment could be pressurized to 200 to $250 \mathrm{psig}$ ( 20 atmospheres) internally. As such, the experiment will have a pressure relief valve that will lift at 200 psig to maintain a pressure below 200 psig in the experiment. The leaking ram will then be isolated and locked out of the gas control system.

\subsection{Quality Assurance}

The design, fabrication, installation, operation, and ATR canal sizing operations of the AGC-1 experiment will comply with all applicable health, safety, and environment requirements. These activities and their corresponding requirement directives are listed in Table 3. 
Table 3. Design Requirements Matrix

\begin{tabular}{|l|l|}
\hline \multicolumn{1}{|c|}{ Activity/ Component } & \multicolumn{1}{c|}{ Requirements } \\
\hline Design, installation, and operation of test lead & $\begin{array}{l}\text { ATR Technical Safety Requirements } \\
\text { Upgraded Final Safety Analysis Report }\end{array}$ \\
\hline Capsule pressure boundary & ASME Boiler and Pressure Vessel Code \\
\hline Mechanical design & Applicable sections of ASME Code \\
\hline Radioactive material shipments & DOE and DOT orders \\
\hline
\end{tabular}

\subsection{Quality Assurance}

Quality assurance activities associated with the AGC-1 experiment will comply with all applicable requirements set forth in the INL Quality Assurance Program. Activities requiring specific quality requirements include, but are not limited to, the following:

- Capsule design review

- Material Procurements

- Capsule fabrication

- Component and system operational testing

- Test calibration

- Operation procedures

- Computer software control

- Irradiation data collection

- Neutron monitor analysis

- Data management

- Data validation

- Reporting.

\section{Program Constraints and Schedule}

Table 4 shows the major milestones for the AGC-1 irradiation experiment.

Table 4. AGC-1 Experiment Milestones

\begin{tabular}{|l|l|}
\hline \multicolumn{1}{|c|}{ AGC-1 Activity } & \multicolumn{1}{c|}{ Milestone Date } \\
\hline Preliminary AGC-1 test train design review meeting & May 25, 2006 \\
\hline Preliminary AGC-1 gas control system design review meeting & July 17, 2006 \\
\hline Final AGC-1 test train design review & August 15, 2006 \\
\hline Complete AGC-1 mock-up assembly & September 21, 2006 \\
\hline Complete bench-top testing & September 21, 2006 \\
\hline Final AGC-1 gas control system design review & December 12, 2006 \\
\hline AGC-1 ATRC run & February 6, 2007 \\
\hline Complete AGC-1 test train assembly & March 5, 2007 \\
\hline Complete installation of AGC-1 gas control system in ATR & August 16, 2007 \\
\hline Insert AGC-1 test train in Cycle 141A and complete SO testing of gas control system & November 17, 2007 \\
\hline Remove AGC-1 test train in Cycle 142B and transfer to ATR Canal & April 19, 2008 \\
\hline
\end{tabular}




\section{References}

1 Bratton, R. L., and T. D. Burchell, NGNP Graphite Testing and Qualification Specimen Selection Strategy, INL/EXT-05-00269, May 2005.

2 Senn, R. L., Design, Operation, and Initial Results from OC-1 Capsules OC-1, the First of a Series of Graphite Creep Irradiations Experiments, ORNL/TM-5798, May 1977.

3 Parry, J. R., Conceptual Neutronics Studies of the AGC-1 Graphite Capsule in the ATR South Flux Trap, EDF-6628, in preparation. 